\title{
Simple fluorescent pyrimidine analogs detect the presence of DNA abasic sites
}

Nicholas J. Greco and Yitzhak Tor*

Department of Chemistry and Biochemistry, University of California, San Diego

La Jolla, California 92093-0358

\section{Supporting Information:}

- S.1 Synthetic Procedures and Experimental Data $\left({ }^{1} \mathrm{H}-\mathrm{NMR},{ }^{13} \mathrm{C}-\mathrm{NMR}, \mathrm{MS}, \mathrm{UV}-\mathrm{Vis}\right)$.

- S.2 Oligonucleotide Synthesis and Purification.

- S.3 Oligonucleotide Sequencing Using MALDI-TOF MS.

- Figure S3.1 MALDI-TOF MS Spectra of Oligonucleotide Digestion.

- S.4 Thermal Denaturation Studies.

- Figure S4.1 Denaturation Plots of Duplexes 6•8, 5•6, 7•8 and $5 \bullet 7$.

- S.5 Quantum Yield Determination.

- S.6 Solvent Polarity Measurements.

- Table S6.1 Relationship between Emission Energy and $\mathrm{E}_{\mathrm{T}}(30)$ Values.

- S.7 Steady State Fluorescence and Absorption Spectra.

- Figure S7.1 Absorption, Excitation and Emission Spectra of 2a and 2b.

- Figure S7.2 Absorption, Excitation and Emission Spectra of 2c and 2d.

- Figure S7.3 Absorption of Duplexes 6•8, 5•6 and $5 \bullet 7$.

- Figure S7.4 Subtracted Absorption of Duplexes 6•8, 5•6 and $5 \bullet 7$.

- $\quad$ S.8 Temperature Dependent Fluorescence Spectra.

- Figure S8.1 Fluorescence Spectra of 2a at Various Temperatures from $25-75^{\circ} \mathrm{C}$.

- Figures S8.2a and $\mathbf{b}$ Fluorescence Spectra of 5 at Various Temperatures from 25$75^{\circ} \mathrm{C}$.

- Figure S8.3 Fluorescence Spectra of $\mathbf{5 \bullet 6}$ at Various Temperatures from $25-75^{\circ} \mathrm{C}$.

- S.9 Crystal Structures of $2 a-2 c$. 


\section{General Procedures}

NMR spectra were recorded on a Varian Mercury $400 \mathrm{MHz}$ spectrometer. Mass spectra were recorded at the UCSD Chemistry and Biochemistry Mass Spectrometry Facility, utilizing either a LCQDECA (Finnigan) ESI with a quadrapole ion trap or a MAT900XL (ThermoFinnigan) FAB double focusing mass spectrometer. UV-Vis spectra were recorded on either a Hewlett Packard 8452A or 8453 Diode Array Spectrometer. Unless otherwise specified, materials obtained from commercial suppliers were used without further purification. Anhydrous pyridine and acetonitrile were obtained from Fluka. Anhydrous dioxane and triethylamine were obtained from Acros. Anhydrous toluene was obtained using a two-column purification system (Glasscontour System, Irvine, CA). NMR solvents were purchased from Cambridge Isotope Laboratories (Andover, MA).

Abbreviations used:

DMT-Cl 4,4'-dimethoxytrityl-chloride

Buffer $\quad 0.01 \mathrm{M}$ sodium phosphate, $0.1 \mathrm{M}$ sodium chloride, $\mathrm{pH}=7.0$

IdUrd (+)-5-iodo-2'-deoxyuridine

THF tetrahydrofuran 
S.1 Synthetic Procedures and Experimental Data $\left({ }^{1} \mathrm{H}-\mathrm{NMR},{ }^{13} \mathrm{C}-\mathrm{NMR}, \mathrm{MS}, \mathrm{UV}-\mathrm{Vis}\right)$.

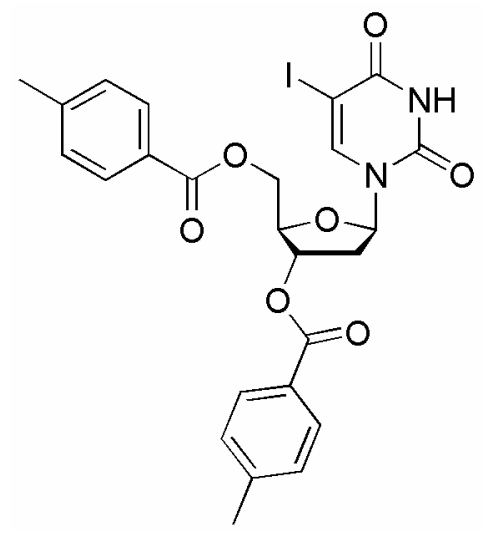

\section{$1 \mathrm{~b} \quad$ 3',5'-Di-O-p-toluoyl-(+)-5-iodo-2'-deoxyuridine}

Anhydrous pyridine $(5 \mathrm{ml})$ was added to IdUrd $(1.00 \mathrm{~g}, 2.82 \mathrm{mmol})$ and stirred under an Ar atmosphere until all IdUrd was dissolved. The solution was cooled to $0{ }^{\circ} \mathrm{C}$ and $p$-toluoyl chloride $(785 \mu \mathrm{l}, 918 \mathrm{mg}, 5.94 \mathrm{mmol})$ was added dropwise. Reaction was allowed to warm to room temperature and stirred under Ar overnight. Water was added to the reaction solution and the precipitate filtered off. Resulting solid was washed with cold water, cold ethanol and then cold ether. Product: white solid (1.42 g, $2.41 \mathrm{mmol}, 85 \%$ yield). ${ }^{1} \mathrm{H}$ NMR (400 MHz, DMSO$\left.d_{6}\right): \delta 11.76(\mathrm{~s}, \mathrm{NH}, 1 \mathrm{H}), 8.09(\mathrm{~s}, \mathrm{H}-6,1 \mathrm{H}), 7.90(\mathrm{t}, J=7.8 \mathrm{~Hz}, \mathrm{Tol}, 4 \mathrm{H}), 7.34$ (t, $J=8.8 \mathrm{~Hz}, \mathrm{Tol}$, 4H), 6.22 (t, J = 7.0 Hz, H-1', 1H), $5.57-5.56$ (m, H-3', 1H), 4.60 (d, J=4.8 Hz, H-5', 2H), 4.52 - 4.49 (m, H-4', 1H), 2.67 - 2.60 (m, H-2', 2H), 2.39 (s, Tol-CH $3,3 \mathrm{H}), 2.38$ (s, Tol-CH $3,3 \mathrm{H})$; ${ }^{13} \mathrm{C}$ NMR (100 MHz, DMSO- $d_{6}$ ): $\delta 165.5$ (Tol-carbonyl), 165.2 (Tol-carbonyl), 160.4 (C-4), 150.0 (C-2), 144.6 (C-6), 144.1 (Tol - C-4), 143.9 (Tol - C-4), 129.4 (Tol - C-2,3,5, and 6), 126.5 (Tol - C-1), 85.3 (C-1'), 81.5 (C-4'), 74.5 (C-3'), 70.1 (C-5), 64.2 (C-5'), 36.4 (C-2'), 21.2 (Tol$\mathrm{CH}_{3}$ ); ESI-MS calculated for $\mathrm{C}_{25} \mathrm{H}_{23} \mathrm{IN}_{2} \mathrm{NaO}_{7}[\mathrm{M}+\mathrm{Na}]^{+}$613.04, found 612.97 . 


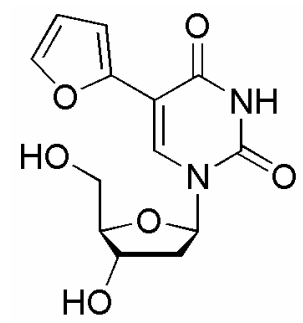

\section{2a 5-(fur-2-yl)-2'-deoxythymidine}

To a suspension of IdUrd (520 mg, $1.47 \mathrm{mmol})$ and dichlorobis(triphenylphosphine)Pd(II) (21 $\mathrm{mg}, 0.03 \mathrm{mmol})$ in anhydrous dioxane $(40 \mathrm{ml})$ was added 2-(tributylstannyl)furan $(2 \mathrm{ml}, 2.26 \mathrm{~g}$, $6.35 \mathrm{mmol}$ ). The suspension was heated to $90{ }^{\circ} \mathrm{C}$ under argon for $2 \mathrm{~h}$, cooled, and filtered through celite 545. The solvent was removed under reduced pressure where the resulting oil was triturated with hexanes $(3 \mathrm{x})$ to produce a solid. The resulting solid was taken up in a minimum of hot solvent (1/1 methanol/chloroform) and precipitated from hexanes. Product: white solid (407.7 mg, 1.39 mmol, $94 \%$ yield). ${ }^{1} \mathrm{H}$ NMR (400 MHz, DMSO-d $)$ ): $\delta 11.63$ (s, NH, 1H), 8.33 (s, H-6, 1H), 7.62 (s, H-5", 1H), 6.86 (d, $J=2.8$ Hz, H-3", 1H), 6.52 (m, 1H, H-4"), 6.22 (t, $J=$ $\left.6.6 \mathrm{~Hz}, 1 \mathrm{H}, \mathrm{H}-1^{\prime}\right), 5.27$ (d, $\left.J=4.4 \mathrm{~Hz}, 1 \mathrm{H}, 3^{\prime}-\mathrm{OH}\right), 5.08$ (t, $\left.J=4.4 \mathrm{~Hz}, 1 \mathrm{H}, 5^{\prime}-\mathrm{OH}\right), 4.28$ (m, 1H, H-3'), $3.84\left(\mathrm{~m}, 1 \mathrm{H}, \mathrm{H}-4^{\prime}\right), 3.61\left(\mathrm{~m}, 2 \mathrm{H}, \mathrm{H}-5^{\prime}\right), 2.18\left(\mathrm{t}, J=5.4 \mathrm{~Hz}, 2 \mathrm{H}, \mathrm{H}-2^{\prime}\right) ;{ }^{13} \mathrm{C}$ NMR $(100$ MHz, DMSO- $\left.d_{6}\right): \delta 160.1$ (C-4), 149.4 (C-2), 146.5 (C-2"), 141.5 (C-5"), 134.7 (C-6), 111.6 (C4"), 107.9 (C-3"), 105.6 (C-5), 87.6 (C-4'), 84.7 (C-1'), 70.4 (C-3'), 61.1 (C-5'), 40.1 (C-2'); HR-

FAB calculated for $\mathrm{C}_{13} \mathrm{H}_{15} \mathrm{~N}_{2} \mathrm{O}_{6}[\mathrm{M}+\mathrm{H}]^{+} 295.0925$, found: 295.0928 ; $\mathrm{UV}$ (buffer) $\lambda_{\max }=316 \mathrm{~nm}$ $(\varepsilon=11,000)$. 


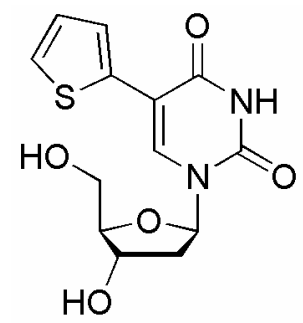

\section{2b 5-(thiophen-2-yl)-2'-deoxythymidine}

To a suspension of IdUrd (521 mg, $1.47 \mathrm{mmol})$ and dichlorobis(triphenylphosphine)Pd(II) (20 $\mathrm{mg}, 0.028 \mathrm{mmol})$ in anhydrous dioxane $(40 \mathrm{ml})$ was added 2-(tributylstannyl)thiophene $(2.5 \mathrm{ml}$, $2.9 \mathrm{~g}, 7.9 \mathrm{mmol}$ ). The suspension was heated to $95^{\circ} \mathrm{C}$ under argon for $5 \mathrm{~h}$, cooled, and filtered through celite 545. The solvent was removed under reduced pressure and the resulting oil was triturated with hexanes $(3 \mathrm{x})$ to produce a solid. The resulting solid was taken up in a minimum of hot solvent (1/1 methanol/chloroform) and precipitated from hexanes. Product: white solid. (242 mg, 0.779 mmol, $53 \%$ yield). ${ }^{1} \mathrm{H}$ NMR (400 MHz, DMSO- $\left.d_{6}\right): \delta 11.7$ (s, NH, 1H), 8.57 (s, H-6, 1H), 7.45 (d, $J=5.2$ Hz, H-5", 1H), 7.40 (d, $J=3.2 \mathrm{~Hz}, \mathrm{H}-3 ", 1 \mathrm{H}), 7.05$ (t, $J=4.4 \mathrm{~Hz}, \mathrm{H}-$ 4"), $6.22\left(\mathrm{t}, J=6.2 \mathrm{~Hz}, \mathrm{H}-1^{\prime}, 1 \mathrm{H}\right), 5.28$ (m, 5'-OH and 3'-OH, 2H), 4.31 (m, H-3', 1H), 3.85 (m, H-4', 1H), 3.66 (m, H-5', 2H), 2.21 (m, H-2', 2H); ${ }^{13} \mathrm{C}$ NMR (100 MHz, DMSO- $\left.d_{6}\right): \delta 161.3(\mathrm{C}-$ 4), 149.4 (C-2), 135.7 (C-6), 134.0 (C-2"), 126.4, 125.7, and 122.5 (C-3", C-4" and C-5"), 108.3 (C-5), 87.6 (C-4'), 84.8 (C-1'), 70.0 (C-3'), 60.9 (C-5'), 40.4 (C-2'); $\quad$ HR-FAB calculated for $\mathrm{C}_{13} \mathrm{H}_{15} \mathrm{~N}_{2} \mathrm{O}_{5} \mathrm{~S}[\mathrm{M}+\mathrm{H}]^{+} 311.0696$, found: 311.0701 ; UV (buffer) $\lambda_{\max }=314 \mathrm{~nm}(\varepsilon=9,000)$ 


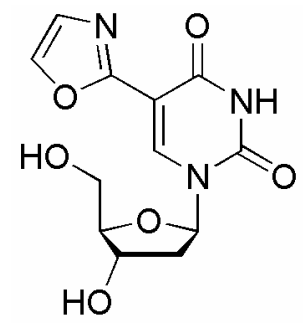

\section{2c 5-(oxazol-2-yl)-2'-deoxythymidine}

To a solution $\mathbf{1 b}(98 \mathrm{mg}, 0.17 \mathrm{mmol})$ and tetrakis(triphenylphosphine) $\mathrm{Pd}(0)$ (20 $\mathrm{mg}, 0.017$ $\mathrm{mmol})$ in anhydrous toluene $(3 \mathrm{ml})$ was added 2-(tributylstannyl)oxazole (106 $\mu 1,181 \mathrm{mg}, 0.506$ mmol). The solution was refluxed under argon for $8 \mathrm{~h}$, cooled and the solvent removed under reduced pressure. The resulting solid was taken up in $20 \%$ methanol/chloroform and run through a silica plug where fractions were collected. Those containing the desired product (fluorescent spot) were consolidated, solvent evaporated under reduced pressure, and resulting solid was taken up in 5\% THF/methanol $(3 \mathrm{ml})$ and $\mathrm{K}_{2} \mathrm{CO}_{3}(23 \mathrm{mg}, 0.17 \mathrm{mmol})$ was added. The suspension stirred at $\mathrm{rt}$ for $12 \mathrm{~h}$. The solvent was removed under reduced pressure and product was isolated by flash chromatography (85/15 chloroform/methanol). Resulting solid was triturated with hexanes. Product: white solid (5 mg, $0.02 \mathrm{mmol}, 10 \%$ yield). ${ }^{1} \mathrm{H}$ NMR (400 MHz, DMSO-d $)_{6}: \delta 11.65$ (s, NH, 1H), 8.58 (s, H-6, 1H), 8.11 (s, H-5", 1H), 7.26 (s, H-4", 1H), $6.17\left(\mathrm{t}, J=6.6 \mathrm{~Hz}, \mathrm{H}-1^{\prime}, 1 \mathrm{H}\right), 5.24\left(\mathrm{~d}, J=3.6 \mathrm{~Hz}, 3^{\prime}-\mathrm{OH}, 1 \mathrm{H}\right), 5.00\left(\mathrm{t}, \mathrm{J}=4.6 \mathrm{~Hz}, 5^{\prime}-\mathrm{OH}, 1 \mathrm{H}\right)$, 4.25 (m, H-3', 1H), 3.85 (m, H-4', 1H), 3.58 (m, H-5', 2H), 2.19 (m, H-2', 2H); ${ }^{13} \mathrm{C}$ NMR (100 MHz, DMSO- $\left.d_{6}\right): \delta 159.6$ (C-4), 156.6 (C-2"), 149.6 (C-2), 142.1 (C-6), 139.6 (C-5"), 127.7 (C4"), 102.9 (C-5), 87.8 (C-4'), 85.2 (C-1'), 70.3 (C-3'), 61.0 (C-5'), 40.3 (C-2'); ESI-MS calculated for $\mathrm{C}_{12} \mathrm{H}_{13} \mathrm{~N}_{3} \mathrm{NaO}_{6}[\mathrm{M}+\mathrm{Na}]^{+} 318.07$, found 317.99. UV (buffer) $\lambda_{\max }=296 \mathrm{~nm}(\varepsilon=10,000)$ 


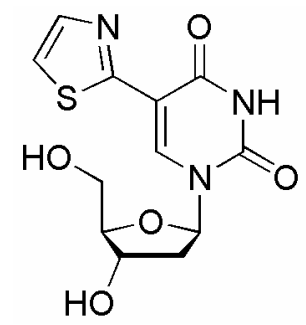

\section{2d 5-(thiazol-2-yl)-2'-deoxythymidine}

To a solution of $\mathbf{1 b}$ (104 mg, $0.176 \mathrm{mmol})$ and dichlorobis(triphenylphosphine)Pd(II) (24 mg, $0.033 \mathrm{mmol})$ in anhydrous dioxane $(3 \mathrm{ml})$ was added 2-(tributylstannyl)thiazole $(160 \mu 1,190 \mathrm{mg}$, $0.509 \mathrm{mmol})$. The solution was refluxed at $90{ }^{\circ} \mathrm{C}$ under argon for $20 \mathrm{~h}$, cooled and the solvent was removed under reduced pressure. The resulting solid was triturated with methanol. The precipitate was taken up in 5\% THF/methanol $(3 \mathrm{ml})$ and $\mathrm{K}_{2} \mathrm{CO}_{3}(33 \mathrm{mg}, 0.24 \mathrm{mmol})$ was added. The suspension stirred at $\mathrm{rt}$ for $24 \mathrm{~h}$. The solvent was removed under reduced pressure and product was isolated by flash chromatography (90/10 chloroform/methanol). The resulting solid was triturated with hexanes. Product: white solid (19 mg, $0.061 \mathrm{mmol}, 34 \%$ yield). ${ }^{1} \mathrm{H}$ NMR (400 MHz, DMSO-d $\left.)_{6}\right): \delta 11.93$ (s, NH, 1H), 8.82 (s, H-6, 1H), 7.85 (d, J= 3.2 Hz, H-5", 1H), $7.65(\mathrm{~d}, J=3.2 \mathrm{~Hz}, \mathrm{H}-4 ", 1 \mathrm{H}), 6.21$ (t, $J=6.6 \mathrm{~Hz}, \mathrm{H}-1$ ', $1 \mathrm{H}), 5.29$ (d, $\left.J=4.4 \mathrm{~Hz}, 3^{\prime}-\mathrm{OH}, 1 \mathrm{H}\right)$, $5.01\left(\mathrm{t}, J=5.0 \mathrm{~Hz}, 5^{\prime}-\mathrm{OH}, 1 \mathrm{H}\right), 4.29-4.25(\mathrm{~m}, \mathrm{H}-3$ ', 1H), $3.88-3.86(\mathrm{~m}, \mathrm{H}-4$ ', $1 \mathrm{H}), 3.61-3.58$ (m, H-5', 2H), 2.23 - $2.19(\mathrm{~m}, \mathrm{H}-2$ ', $2 \mathrm{H}) ;{ }^{13} \mathrm{C}$ NMR (100 MHz, DMSO-d $\left.{ }_{6}\right): \delta 161.3(\mathrm{C}-4), 158.1$ (C-2"), 149.4 (C-2), 141.8 (C-4"), 138.5 (C-6), 119.8 (C-5"), 107.6 (C-5), 87.8 (C-4'), 85.3 (C1'), $70.5\left(\mathrm{C}-3^{\prime}\right), 61.3\left(\mathrm{C}-5^{\prime}\right), 40.1$ (C-2'); ESI-MS calculated for $\mathrm{C}_{12} \mathrm{H}_{13} \mathrm{~N}_{3} \mathrm{NaO}_{5} \mathrm{~S}[\mathrm{M}+\mathrm{Na}]^{+}$ 334.05, found 333.94; UV (buffer) $\lambda_{\max }=316 \mathrm{~nm}(\varepsilon=11,500)$. 




\section{5'-dimethoxytrityl-5-(fur-2-yl)-2'-deoxythymidine}

To a solution of 2a (163 mg, $0.554 \mathrm{mmol})$ and DMT-Cl (226 mg, $0.669 \mathrm{mmol})$ in anhydrous pyridine $(3 \mathrm{ml})$ was added triethylamine $(60 \mu \mathrm{l})$. The reaction was stirred at room temperature under argon for $4 \mathrm{hr}$ and evaporated under reduced pressure. The product was purified by flash column chromatography (1/1 ethylaceate/hexanes, $\left.1 \% \mathrm{Et}_{3} \mathrm{~N}\right)$. Product: light brown foam (234 mg, $0.393 \mathrm{mmol}, 71 \%$ yield). ${ }^{1} \mathrm{H}$ NMR (400 MHz, DMSO- $\left.d_{6}\right): \delta 11.70$ (s, NH, 1H), 7.96 (s, H-6, 1H), $7.27-7.16$ (m, DMT and H-5", 10H), $6.84-6.81$ (m, DMT and H-3", 5H), $6.46-6.44$ (m, H-4", 1H), 6.18 (t, $J=6.6 \mathrm{~Hz}, \mathrm{H}-1$ ', 1H), 5.36 (d, $\left.J=4.4 \mathrm{~Hz}, 3^{\prime}-\mathrm{OH}, 1 \mathrm{H}\right), 4.23$ - 4.19 (m, H-3', 1H), $3.96-3.93$ (m, H-4', 1H), 3.69 (s, DMT-OCH $3,6 \mathrm{H}), 3.24-3.15$ (m, H-5', 2H), $2.27-2.24$ (m, H-2', 2H); ${ }^{13} \mathrm{C}$ NMR (100 MHz, DMSO- $\left.d_{6}\right): \delta 160.1,158.0,149.3,146.1,144.7,141.2$, 135.5, 133.9, 129.6, 127.7, 127.6, 126.6, 113.1, 111.4, 107.9, 105.6, 85.8, 85.1, 70.3, 63.6, 55.0, 40.2; ESI-MS calculated for $\mathrm{C}_{34} \mathrm{H}_{32} \mathrm{~N}_{2} \mathrm{NaO}_{8}[\mathrm{M}+\mathrm{Na}]^{+}$619.21, found 619.08. 


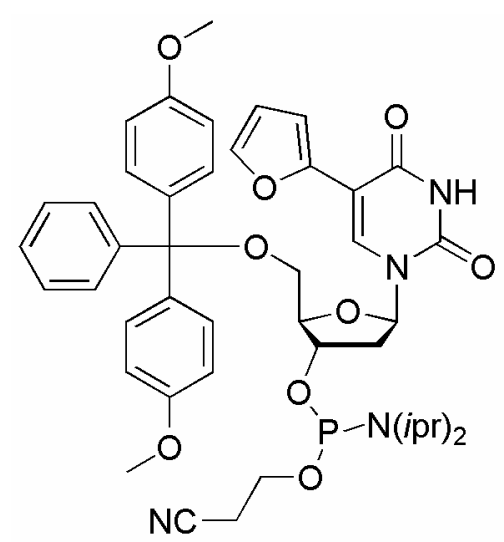

4 3'-2-cyanoethyldiisopropylphosphoramidite-5'-dimethoxytrityl-5-(fur-2-yl)-2'deoxythymidine

3 was taken up in anhydrous acetonitrile and solvent was removed under reduced pressure (5x).

To a solution of $3(58 \mathrm{mg}, 0.10 \mathrm{mmol})$ and $1-H$ tetrazole $(0.45 \mathrm{M}$ solution in acetonitrile: $215 \mu 1$, $0.0968 \mathrm{mmol})$ in anhydrous acetonitrile $(2 \mathrm{ml})$ was added 2-cyanoethyl tetraisopropylphosphorodiamidite $(37 \mu 1,35 \mathrm{mg}, 0.12 \mathrm{mmol})$. The solution was stirred at room temperature under argon for $4 \mathrm{hrs}$. The reaction mixture was diluted with cold $1 \%$ triethylamine/dichloromethane $(100 \mathrm{ml})$ and washed with $1 \mathrm{M} \mathrm{NaHCO}_{3}(2 \mathrm{x} 10 \mathrm{ml})$ and brine $(2 \mathrm{x}$ $10 \mathrm{ml}$ ). The organic layer was dried over sodium sulfate and evaporated under reduced pressure. The product was purified by flash column chromatography (1/1 ethylaceate/hexanes, $\left.1 \% \mathrm{Et}_{3} \mathrm{~N}\right)$. Product: light brown foam (50 mg, $0.063 \mathrm{mmol}, 65 \%$ yield) ${ }^{1} \mathrm{H}$ NMR (400 MHz, DMSO- $d_{6}$ ): $\delta$ 11.60 (s, H-6, 1H), $7.39-7.17$ (m, DMT and H-5', 10H), $6.82-6.79$ (m, DMT and H-3', 5H), $6.45-6.43$ (m, H-4", 1H), 6.17 (t, $J=6.4$ Hz, H-1', 1H), $4.50-4.44$ (m, H-3', 1H), $4.11-4.08$ (m, H-4', 1H), 3.69 - 3.39 (m, DMT-OCH , isopropyl and cyanoethyl, 10H), $3.24-3.19$ (m, H5', 2H), $2.64-2.61$ (m, cyanoethyl, $2 \mathrm{H}), 1.23-1.08$ (m, isopropyl, $12 \mathrm{H}) ;{ }^{13} \mathrm{C} \mathrm{NMR}(100 \mathrm{MHz}$, DMSO- $\left.d_{6}\right): \delta 160.1,158.1,149.2,146.1,144.6,141.2,135.3,134.0,129.7,127.7,127.6,126.6$, $118.7,113.1,111.5,108.0,105.7,85.9,85.2,72.3,63.5,58.5,55.0,42.6,42.5,40.2,24.3,24.3$, 
24.2, 19.8; ${ }^{31} \mathrm{P}$ NMR (162 MHz, DMSO- $d_{6}$, referenced to $\left.\mathrm{H}_{3} \mathrm{PO}_{4}\right): \delta 148.7,148.3$; ESI-MS calculated for $\mathrm{C}_{43} \mathrm{H}_{49} \mathrm{~N}_{4} \mathrm{NaO}_{9} \mathrm{P}[\mathrm{M}+\mathrm{Na}]^{+}$819.31, found 819.14.

\section{S.2 Oligonucleotide Synthesis and Purification.}

Unmodified oligonucleotides were purchased from Intergraded DNA Technologies (Coralville, Iowa) and purified by PAGE as described below. The THF residue in oligonucleotide 7 has the following structure:

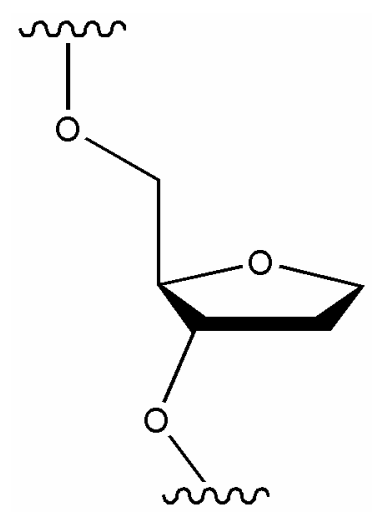

Modified oligonucleotides were synthesized on a $1.0 \mu$ mole scale (500 $\AA$ CPG column) using a Biosearch Cyclone Plus DNA synthesizer. Phosphoramidite 4 was site specifically incorporated into the oligonucleotides by trityl-off synthesis of the base oligonucleotide, followed by manual coupling of phosphoramidite 4. Typically, the modified phosphoramidite was dissolved in $100 \mu \mathrm{L}$ of anhydrous acetonitrile to give a final concentration of $0.1 \mathrm{M}$. The phosphoramidite solution was pushed into the CPG column via syringe and then $200 \mu \mathrm{L}$ of $0.45 \mathrm{M} 1 H$-tetrazole was pushed into the other end of the column via syringe. Coupling reactions were allowed to proceed for 2 - 3 minutes ( $88 \%$ unoptimized coupling efficiency) and were subsequently followed by standard oxidation and capping steps. The rest of the oligonucleotide was synthesized via the standard trityl-off procedure. Upon completion of the oligonucleotide synthesis, the CPG column was treated with $3 \mathrm{~mL}$ of $30 \%$ aqueous ammonium hydroxide for $2 \mathrm{~h}$ 
at room temperature, mixing via syringe every $1 \mathrm{~h}$. The resulting solution was removed and the CPG column was treated with $1 \mathrm{~mL}$ of $30 \%$ aqueous ammonium hydroxide at room temperature for $15 \mathrm{~min}$, mixing via syringe every $5 \mathrm{~min}$. The resulting aqueous ammonium hydroxide solutions were consolidated and stored at room temperature for $24 \mathrm{~h}$. The aqueous ammonium hydroxide solutions were freeze-dried and purified by $20 \%$ polyacrylamide gel electrophoresis. The oligonucleotide was visualized by UV shadowing, bands were excised from the gel, and extracted with 1X TBE buffer for $36 \mathrm{~h}$. The resulting solution was filtered (Bio Rad poly-prep chromatography column) and desalted using a Sep-Pak cartridge (Waters Corporation, MA). The following $260 \mathrm{~nm}$ extinction coefficients were used to determine concentration of oligonucleotides: $\mathrm{dG}=11,700, \mathrm{dC}=7,300, \mathrm{dA}=15,400, \mathrm{dT}=8,800$, and $\mathbf{2 a}=13,000$.

\section{S.3 Oligonucleotide Sequencing Using MALDI-TOF MS.}

The MW of each control and modified oligonucleotide was determined via MALDI-TOF MS. 1 $\mu \mathrm{L}$ of a $200 \mu \mathrm{M}$ stock solution of each oligonucleotide was combined with $1 \mu \mathrm{M}$ ammonium citrate buffer (PE Biosystems), $1 \mu \mathrm{L}$ of a $75 \mu \mathrm{M}$ DNA standard (5'-GCTGAATACATAAGACG $\left.-3^{\prime}\right)$ and $6 \mu \mathrm{L}$ of saturated 3-hydroxypiccolinic acid. The samples were desalted with an ionexchange resin (PE Biosystems) and spotted onto a gold-coated MALDI plate where they were dried on a $55{ }^{\circ} \mathrm{C}$ heat block. The resulting spectra were calibrated relative to the +1 and +2 ions of the internal DNA standard, thus the observed oligonucleotides should have a resolution of \pm 2 mass units. Modified oligonucleotide 5 was sequenced via onplate digestion (Sequazyme Oligonucleotide Sequencing Kit - Applied Biosystems). $2 \mu \mathrm{L}$ of water and $1 \mu \mathrm{L}$ of a $200 \mu \mathrm{M}$ stock solution of oligonucleotide $\mathbf{5}$ were combined and spotted eight times onto a gold-coated MALDI plate. $2 \mu \mathrm{L}$ of SVP dilutions $(1 \mu \mathrm{L}$ of ammonium citrate buffer and $1 \mu \mathrm{L}$ of SVP 
dilution) were added to the first five wells and $2 \mu \mathrm{L}$ of BSP dilutions $(1 \mu \mathrm{L}$ of BSP reaction buffer and $1 \mu \mathrm{L}$ of BSP dilution) were added to the remaining three wells. The MALDI plate was incubated in a humidity chamber (Applied Biosystems) at $37^{\circ} \mathrm{C}$ for $20 \mathrm{~min} .7 \mu \mathrm{L}$ of saturated 3-hydroxypiccolinic acid was added to each well. The samples were desalted with an ion-exchange resin (PE Biosystems) and then respotted onto the same wells of the gold-coated MALDI plate where they were subsequently dried on a $55^{\circ} \mathrm{C}$ heat block. All MALDI-TOF spectra were collected on a PE Biosystems Voyager-DE STR MALDI-TOF spectrometer in positive-ion, delayed-extraction mode. The following nucleoside masses were used to confirm the sequence: $\mathrm{dG}=329.053, \mathrm{dC}=289.046, \mathrm{dA}=313.058, \mathrm{dT}=304.046$, and the modified furan $\mathrm{dT}=356.041$. 
Figure S3.1 MALDI-TOF MS spectra of oligonucleotide 5.

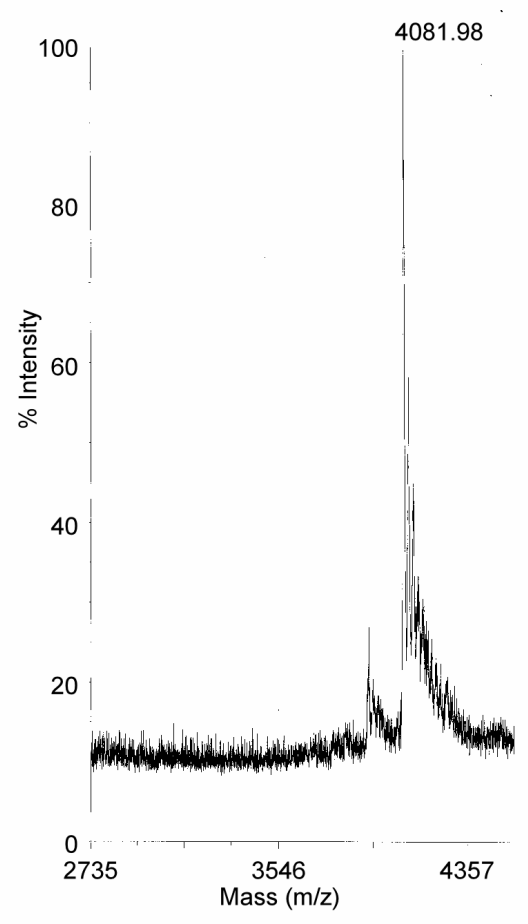

Oligonucleotide 5 calculated mass $=4081.59 ;$ Observed mass $=4081.98$

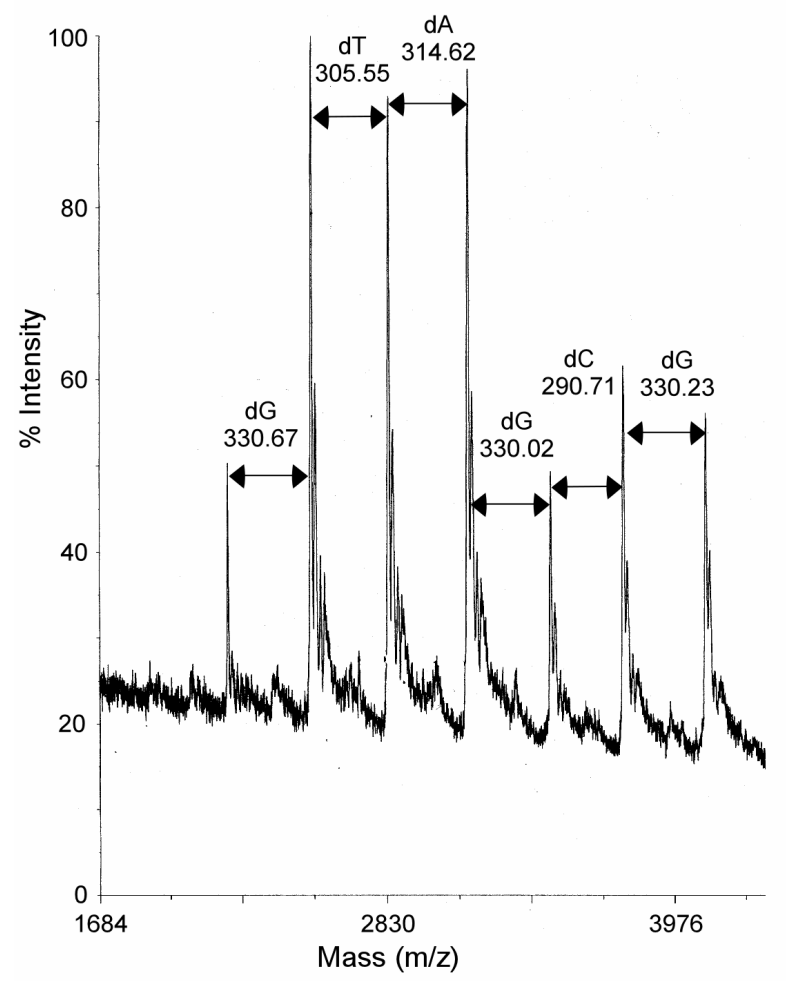

Bovine Spleen Phosphodiesterase Digestion (5' to 3')

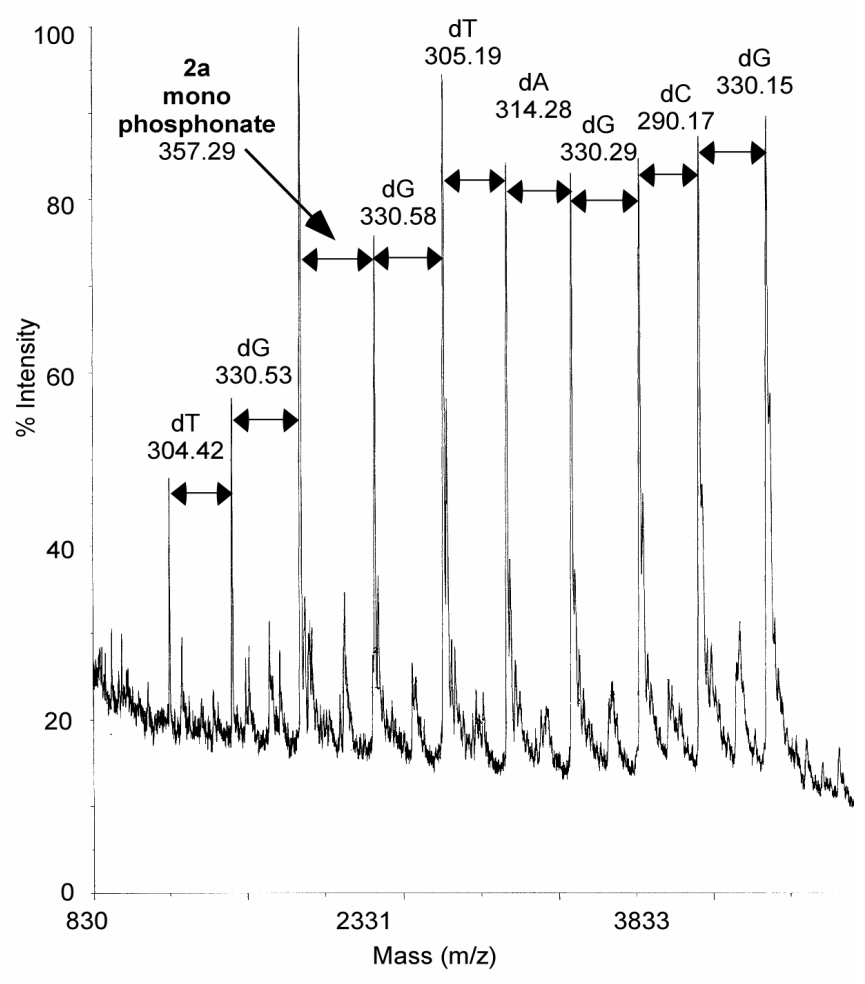

Snake Venom Phosphodiesterase Digestion (3' to 5') 


\section{S.4 Thermal Denaturation Studies.}

All hybridizations and UV melting experiments were carried out in $1.0 \times 10^{-1} \mathrm{M}$ sodium chloride, $2.0 \times 10^{-2} \mathrm{M}$ sodium phosphate buffer at $\mathrm{pH} 7.0$ using a Beckman-Coulter DU ${ }^{\circledR} 640$ spectrometer with a high performance temperature controller and micro auto six holder. Samples (double-stranded concentrations: $1 \mu \mathrm{M}$ ) were heated to $95{ }^{\circ} \mathrm{C}$ for $5 \mathrm{~min}$ and cooled to room temperature over 2-3 h prior to measurements. Samples were placed in a stoppered $1.0-\mathrm{cm}$ path length cell and a background spectra (buffer) was subtracted from each sample. Denaturation runs were performed between 26 and $75^{\circ} \mathrm{C}$ at a scan rate of $0.5{ }^{\circ} \mathrm{C} \mathrm{min}{ }^{-1}$ with optical monitoring every minute at $260 \mathrm{~nm}$. Beckman-Coulter software (provided with Tm Analysis Accessory for $\mathrm{DU}^{\circledR}$ Series 600 Spectrometers) determined the melting temperatures utilizing the first derivative from the melting profile.

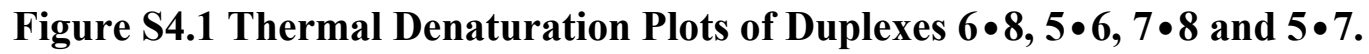
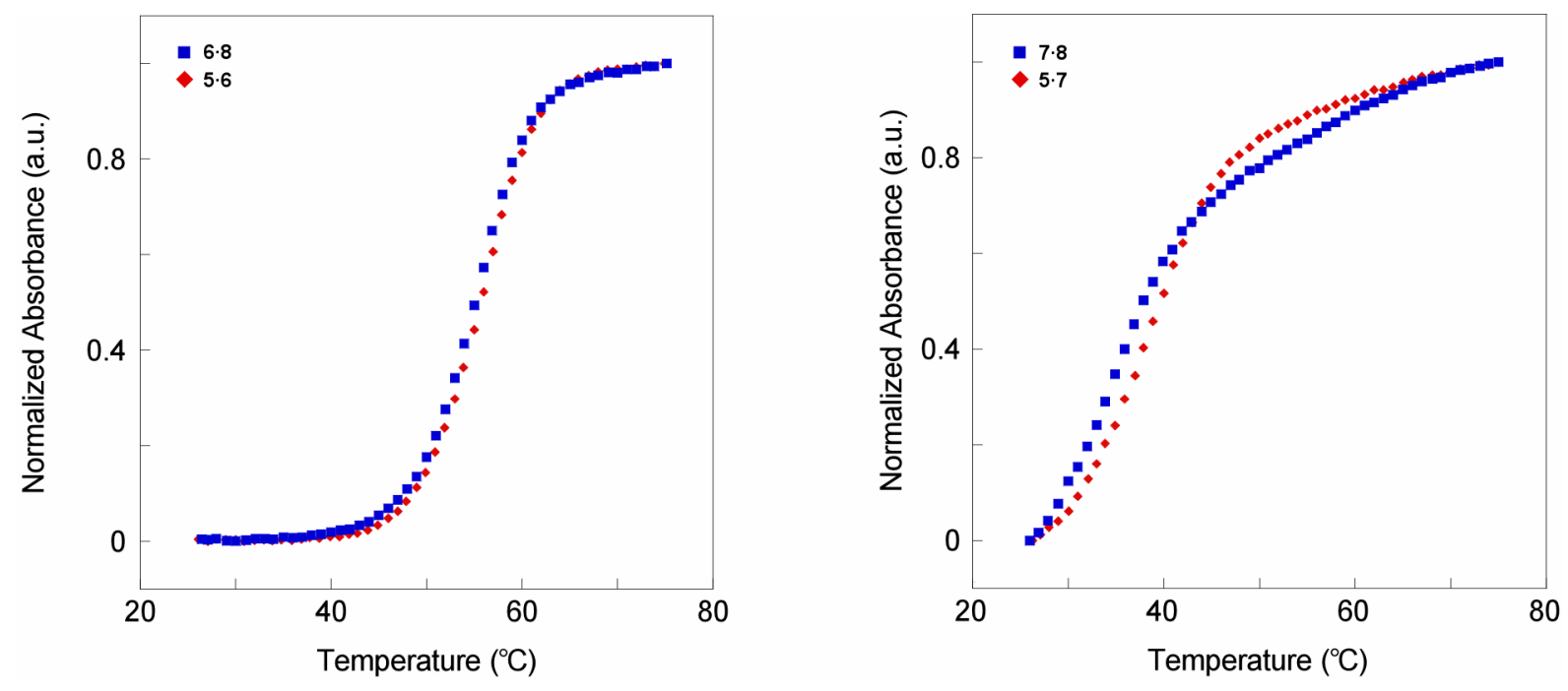


\section{S.5 Quantum Yield Determination.}

Quantum yields were determined using anthracene as a standard (Du, H.; Fuh, R. A.; Li, J.; Corkan, A.; Lindsey, J. S. Photochem. and Photobiol., 1998, 68, 141-142) for nucleosides 2a, 2b and 2d. Quantum yield of nucleoside 2c was determined with respect to nucleoside 2a. Quantum yields of all nucleosides (2a-2d) were determined using the following equation:

$\Phi_{\mathrm{F}(\mathrm{x})}=\left(\mathrm{A}_{\mathrm{s}} / \mathrm{A}_{\mathrm{x}}\right)\left(\mathrm{F}_{\mathrm{x}} / \mathrm{F}_{\mathrm{s}}\right)\left(n_{\mathrm{x}} / n_{\mathrm{s}}\right)^{2} \Phi_{\mathrm{F}(\mathrm{s})}$

Where $\mathrm{s}$ is the standard, $\mathrm{x}$ is the unknown, $\mathrm{A}$ is the absorbance at excitation wavelength, $\mathrm{F}$ is the area under the emission curve, $n$ is the refractive index of the solvent and $\Phi$ is the quantum yield (Lavabre, D.; Fery-Forgues, S. J. Chem. Educ., 1999, 76, 1260-1264).

\section{S.6 Solvent Polarity Measurements.}

The relationship between emission energy and microenvironment solvent polarity $\left[\mathrm{E}_{\mathrm{T}}(30)\right]$ was determined for nucleoside 2a. All emission spectra were determined at $1.0 \times 10^{-5} \mathrm{M}$ with $1 \%$ DMSO in five different solvents (buffer, methanol, acetonitrile, dichloromethane and ether). Emission spectra were converted from wavelength (nm) to wavenumbers $\left(\mathrm{cm}^{-1}\right) . \mathrm{E}_{\mathrm{T}}(30)$ values for each solvent were determined using Reichardt's salt (Reichardt, C. Chem. Rev. 1994, 94, 2319-2358).

Table S6.1 Relationship between Emission Energy and $\mathbf{E}_{\mathbf{T}}(30)$ Values. ${ }^{a}$

\begin{tabular}{ccc}
\hline Solvent & $\mathrm{E}_{\mathrm{T}}(30)$ & Emission Energy of 2a \\
\hline Buffer & 63.1 & 23,202 \\
Methanol & 55.2 & 23,697 \\
Acetonitrile & 45.9 & 24,876 \\
Dichloromethane & 41.4 & 24,938 \\
Ether & 34.9 & 25.316 \\
\hline
\end{tabular}

\footnotetext{
${ }^{a}$ All solvents contained 1\% DMSO for solubility reasons.
} 


\section{S.7 Steady State Fluorescence and Absorption Spectra.}

Steady State fluorescence experiments were carried out at ambient temperature (unless otherwise noted) in a micro fluorescence cell with a path length of $1.0 \mathrm{~cm}$ (Hellma $\mathrm{GmbH} \& \mathrm{Co} \mathrm{KG}$, Müllheim, Germany) on a Perkin Elmer LS 50B luminescence spectrometer. All nucleoside samples were measured at $1.0 \times 10^{-5} \mathrm{M}(1 \% \mathrm{DMSO})$ in the appropriate spectroscopic grade solvent (see figure S7.1 and S7.2 for instrument setup details). All DNA samples (except fluorescence monitored denaturation of a perfect duplex [ Figure $3\left(2.0 \times 10^{-6} \mathrm{M}\right)$ ] $)$ were measured at $1.0 \times 10^{-6} \mathrm{M}$ concentration in $1.0 \times 10^{-1} \mathrm{M}$ sodium chloride, $1.0 \times 10^{-2} \mathrm{M}$ sodium phosphate buffer at $\mathrm{pH} 7.0$ at ambient temperature (excitation slit $=15.0 \mathrm{~nm}$, emission slit $=20.0$ $\mathrm{nm}$, scan speed $=300 \mathrm{~nm} / \mathrm{min}$, spectra averaged over three scans). A blank (buffer) was subtracted for each DNA spectra except for emission of duplex $5 \cdot 6$ and $5 \cdot 7$ where duplex $\mathbf{6 \bullet 8}$ was subtracted for background correction. 
Figure S7.1 Absorption, Excitation and Emission Spectra of 2a and 2b.

Emission and Excitation Spectra: $1.0 \times 10^{-5} \mathrm{M} 1 \%$ DMSO, excitation slit: $10.0 \mathrm{~nm}$, emission slit: $12.0 \mathrm{~nm}$, scan speed $300 \mathrm{~nm} / \mathrm{min}, 1.0 \times 10^{-5}$ M 1\% DMSO dT subtracted, spectra averaged over three scans.

Absorption Spectra: $5.0 \times 10^{-5} \mathrm{M}$ 1\% DMSO, 1\% DMSO in appropriate solvent subtracted.

- Buffer

- Ether
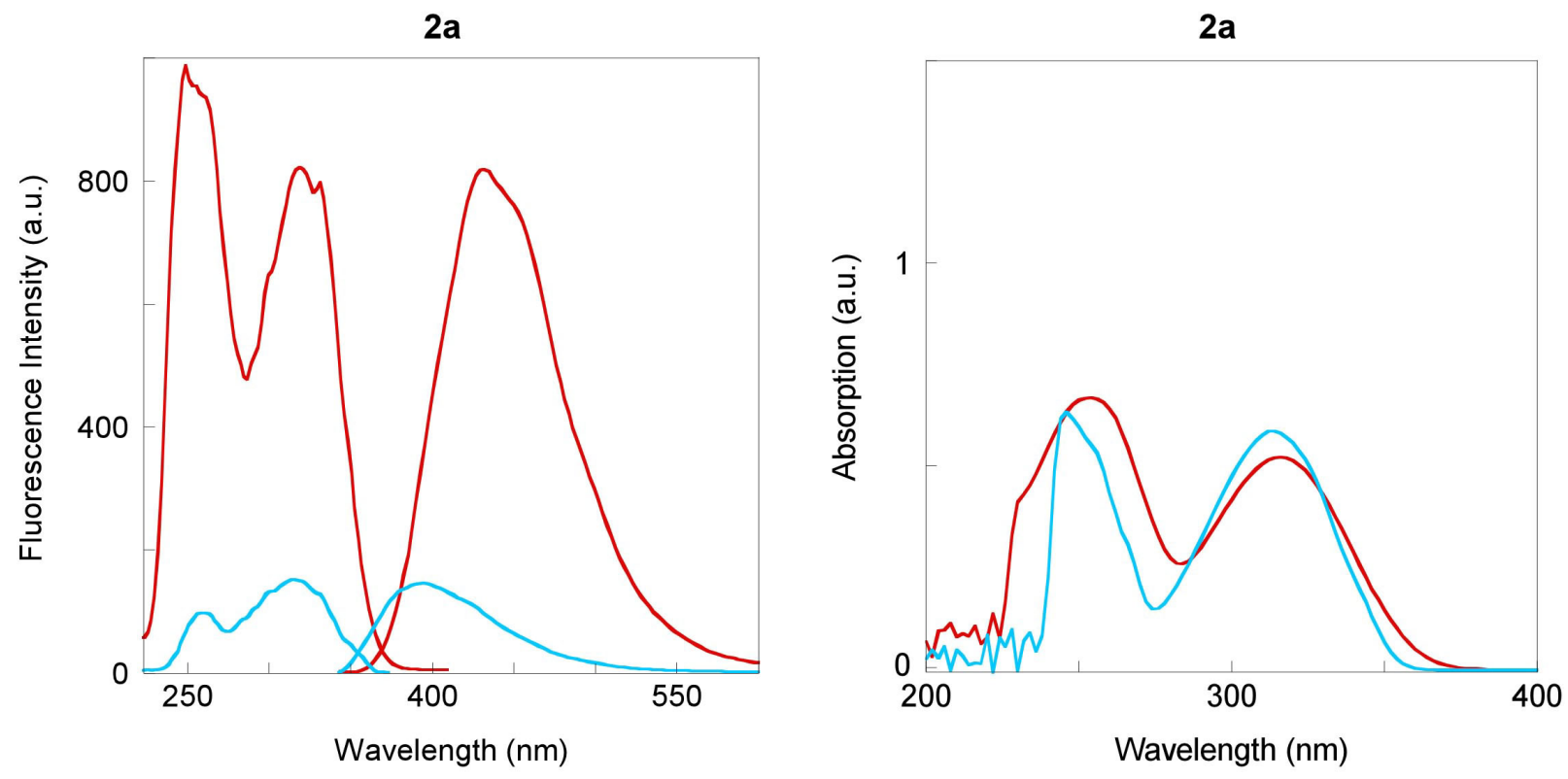

Excitation at $316 \mathrm{~nm}$ for buffer and ether solutions:

Emission monitored at $431 \mathrm{~nm}$ for buffer and $395 \mathrm{~nm}$ for ether solutions
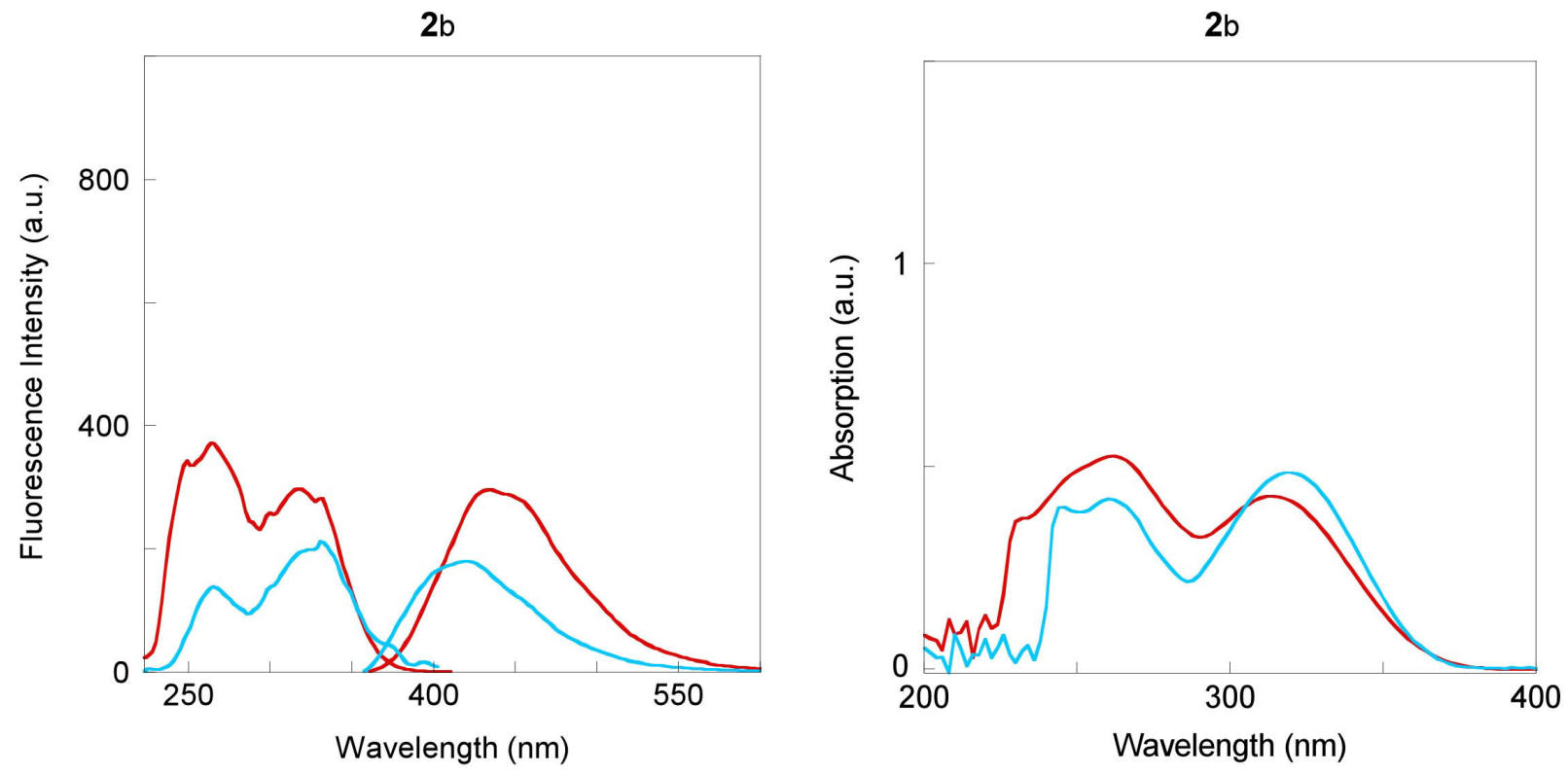

Excitation at $314 \mathrm{~nm}$ for buffer and ether solutions:

Emission monitored at $434 \mathrm{~nm}$ for buffer and $421 \mathrm{~nm}$ for ether solutions 
Figure S7.2 Absorption, Excitation and Emission Spectra of 2c and 2d.

Emission and Excitation Spectra: $1.0 \times 10^{-5} \mathrm{M} 1 \%$ DMSO, excitation slit: $10.0 \mathrm{~nm}$, emission slit: $12.0 \mathrm{~nm}$, scan speed $300 \mathrm{~nm} / \mathrm{min}, 1.0 \times 10^{-5} \mathrm{M} 1 \%$ DMSO dT subtracted, spectra averaged over three scans.

Absorption Spectra: $5.0 \times 10^{-5}$ M 1\% DMSO, 1\% DMSO in appropriate solvent subtracted.

- Buffer

- Ether
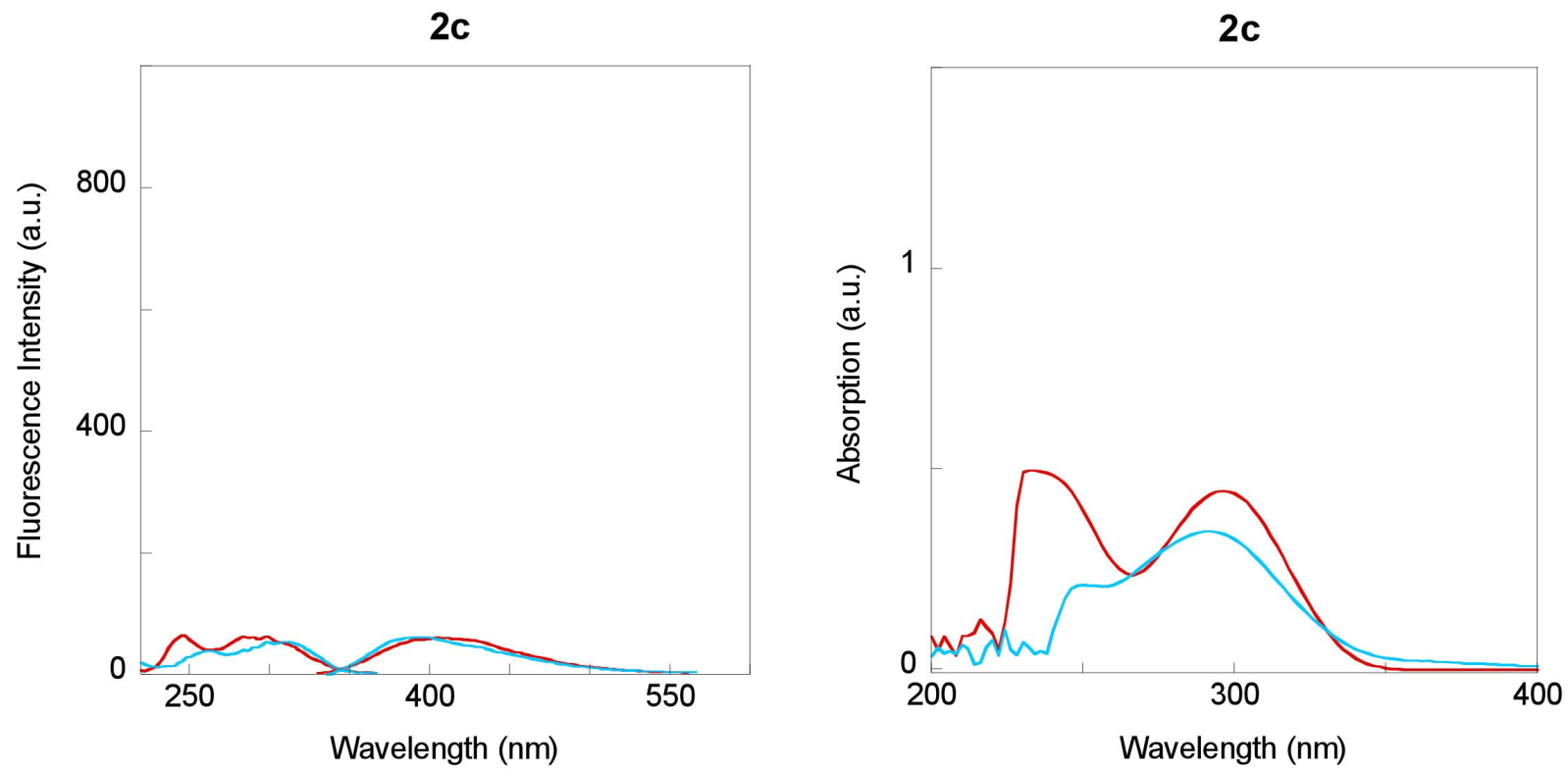

Excitation at $296 \mathrm{~nm}$ for buffer and ether solutions:

Emission monitored at $400 \mathrm{~nm}$ for buffer and $390 \mathrm{~nm}$ for ether solutions
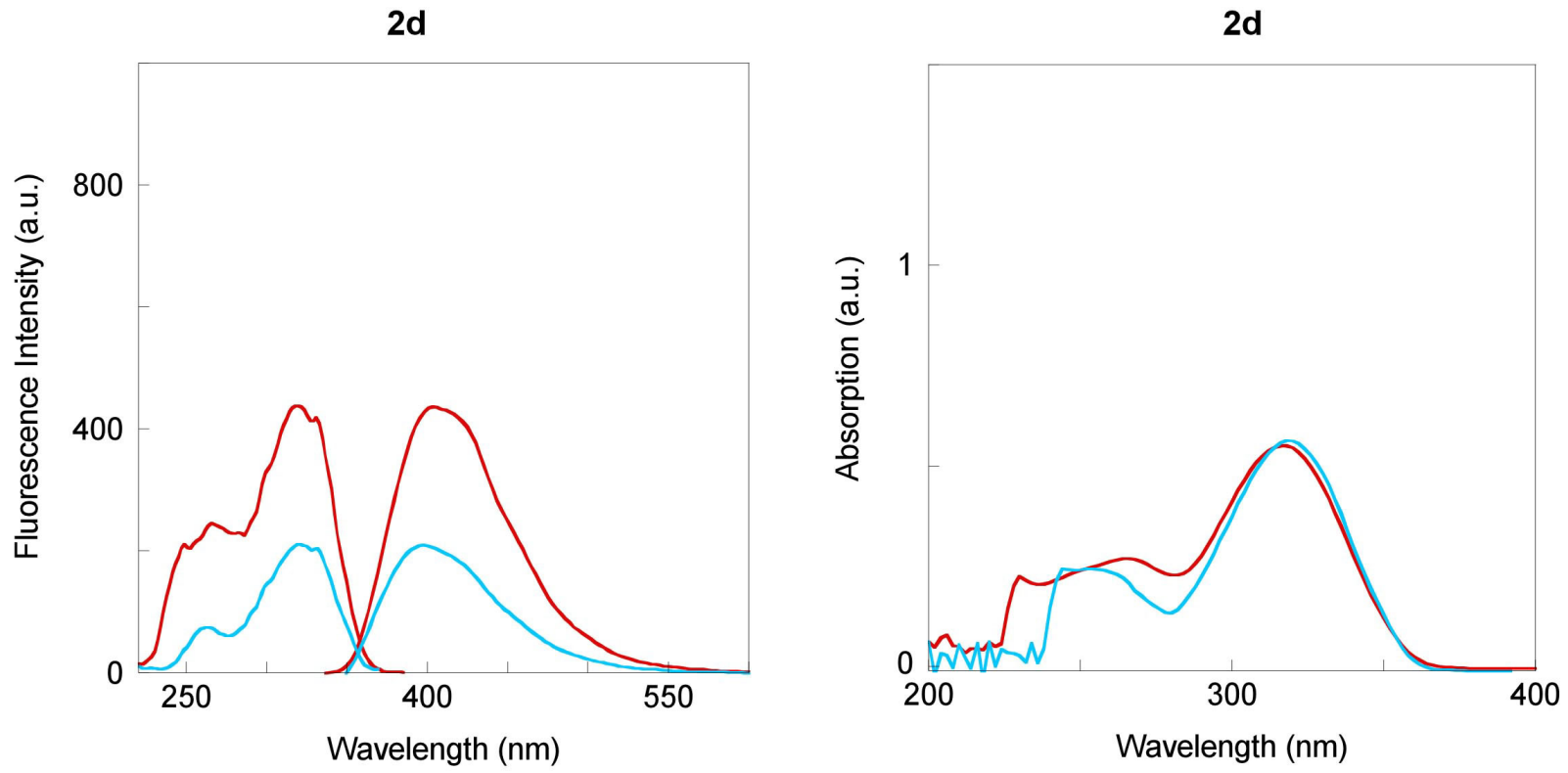

Excitation at $316 \mathrm{~nm}$ for buffer and ether solutions:

Emission monitored at $404 \mathrm{~nm}$ for buffer and $397 \mathrm{~nm}$ for ether solutions 
Figure S7.3 Absorption of Duplexes 6•8, $5 \bullet 6$ and $5 \cdot 7$.

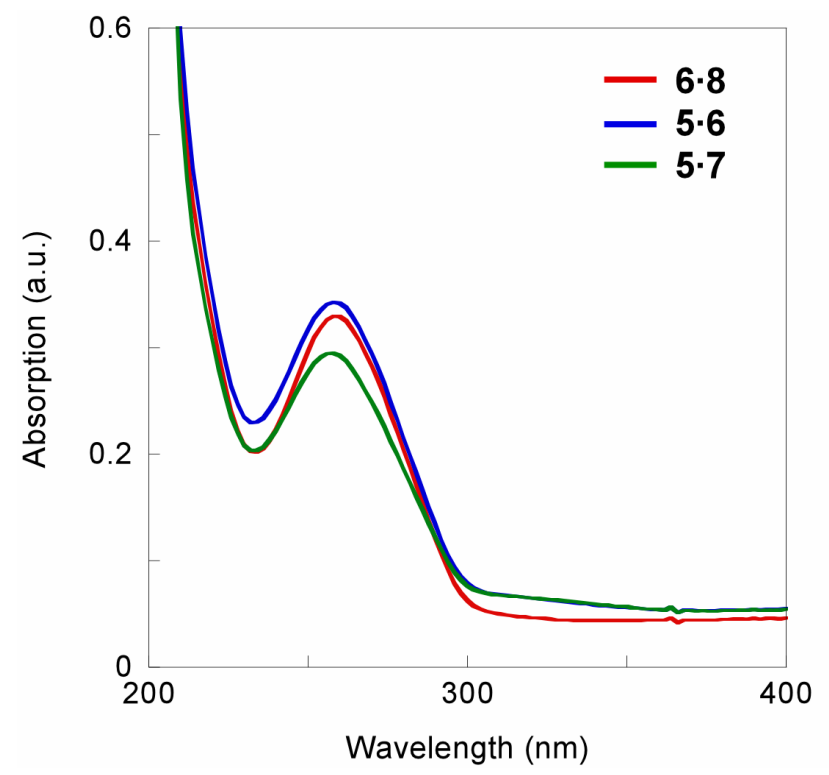

Figure S7.4 Subtracted Absorption of

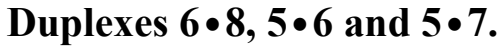

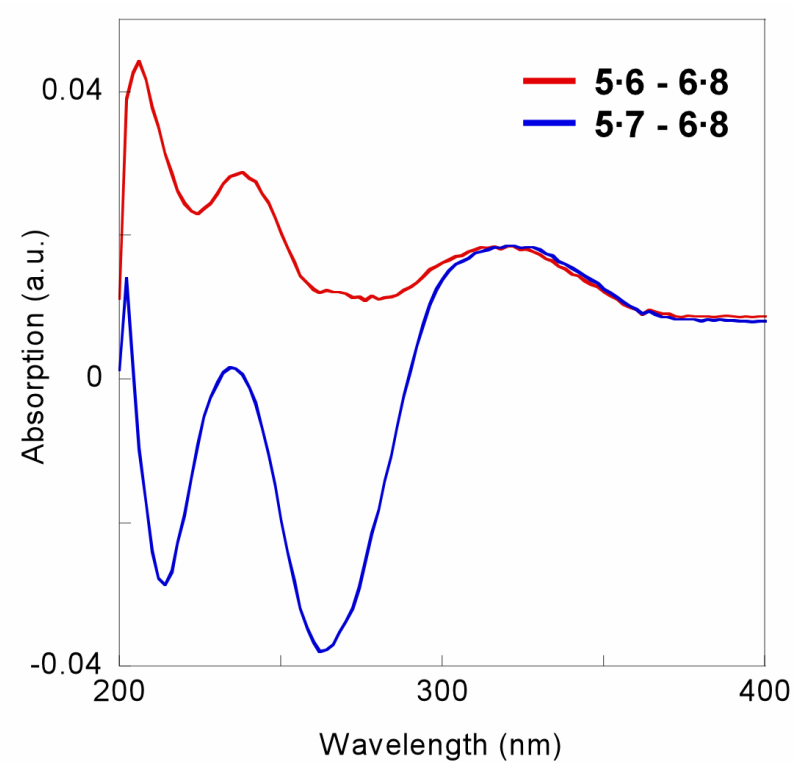

\section{S.8 Temperature Dependent Fluorescence Spectra.}

Temperature dependent fluorescence experiments were carried out at 5 degree intervals from 25 to $75^{\circ} \mathrm{C}$ in a micro fluorescence cell with a path length of $1.0 \mathrm{~cm}(\mathrm{Hellma} \mathrm{GmbH} \& \mathrm{Co} \mathrm{KG}$, Müllheim, Germany) using a temperature controlled cell holder connected to an external waterbased temperature control unit on a Perkin Elmer LS 50B luminescence spectrometer. All nucleoside samples were measured at $1.0 \times 10^{-5} \mathrm{M}(1 \% \mathrm{DMSO})$ in buffer. All DNA samples were measured at $2.0 \times 10^{-6} \mathrm{M}$ in buffer (excitation slit $=15.0 \mathrm{~nm}$, emission slit $=20.0 \mathrm{~nm}$, scan speed $=300 \mathrm{~nm} / \mathrm{min}$, spectra averaged over three scans). A blank (buffer) was subtracted for each DNA spectra. Spectra at the appropriate temperature were recorded after allowing the sample to equilibrate for $14 \mathrm{~min}$. 
The emission of $\mathbf{2 a}$ is inherently temperature dependent and decreases as the temperature increases, most likely due to thermal population of non-radiative decay pathways (Figure S8.1). Similar behavior is observed for the single stranded oligonucleotide 5. Note, this temperature dependence is completely reversible (Figure S8.2a and $\mathbf{b}$ ). This temperature dependence causes the initial decrease in emission seen between $10-45^{\circ} \mathrm{C}$ in Figure 4 (text). See also Figure S8.3 that illustrates the individual emission spectra used to generate Figure 4.

Figure S8.1 Fluorescence Spectra of 2a at Various Temperatures from $25-75^{\circ} \mathrm{C}$.

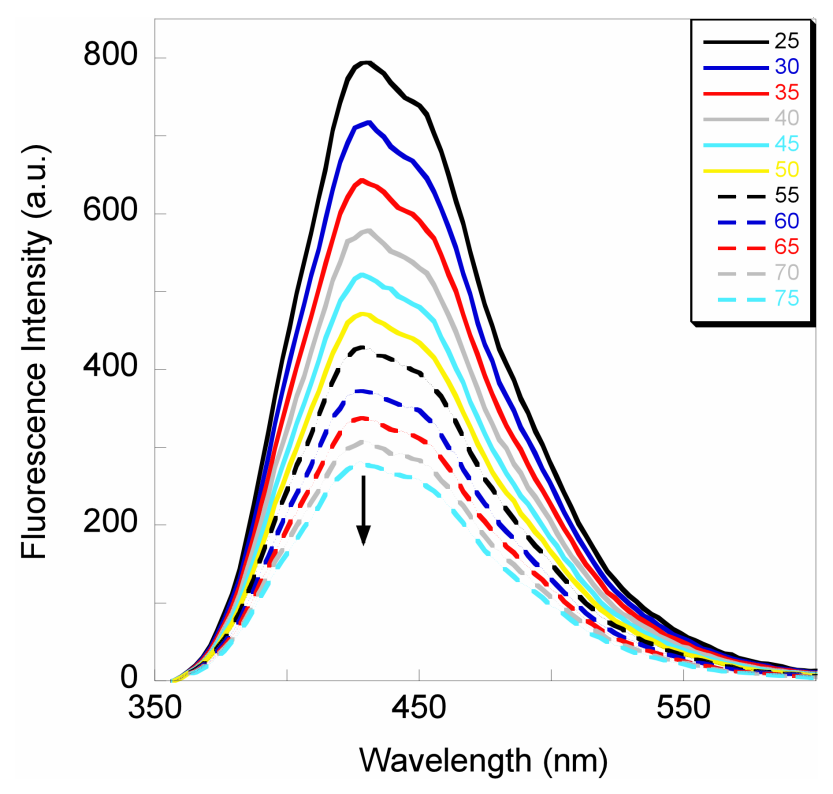


Figure S8.2a and b Fluorescence Spectra of 5 at Various Temperatures from $25-75^{\circ} \mathrm{C}$.

Figure S8.2a Fluorescence Monitored Upon Temperature Increase $\left(25-75^{\circ} \mathrm{C}\right)$.

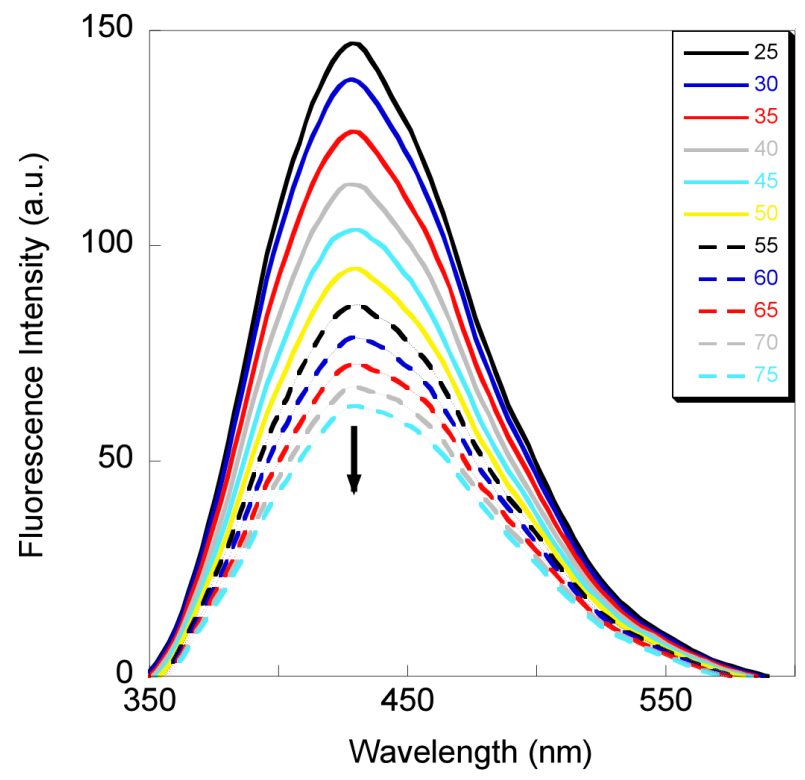

Figure S8.2b Fluorescence Monitored Upon Temperature Decrease $\left(7^{2}-2^{\circ} \mathrm{C}\right)$.

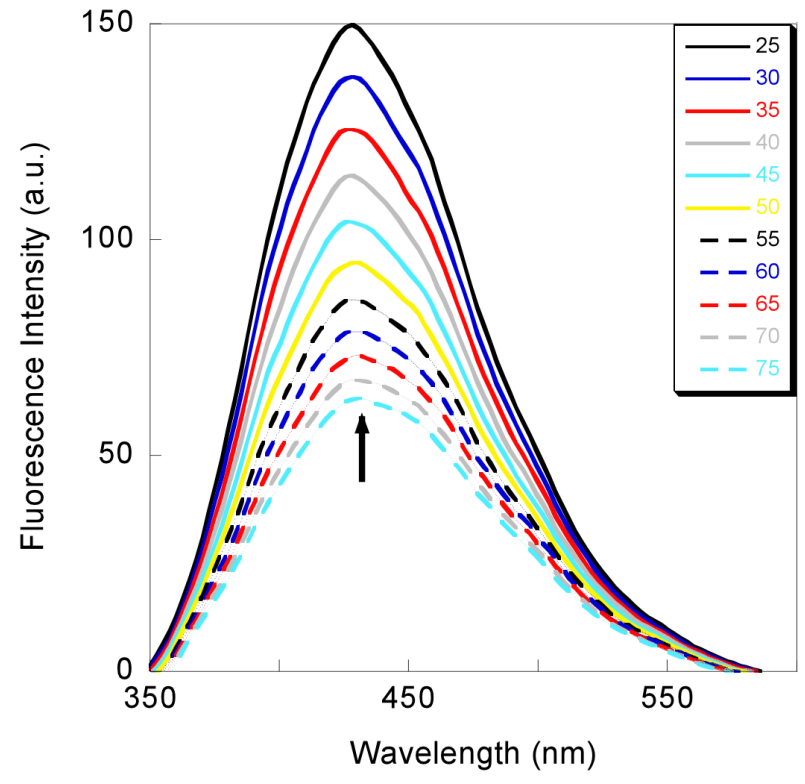

Figure S8.3 Fluorescence Spectra of $5 \bullet 6$ at Various Temperatures from $25-75^{\circ} \mathrm{C}$.

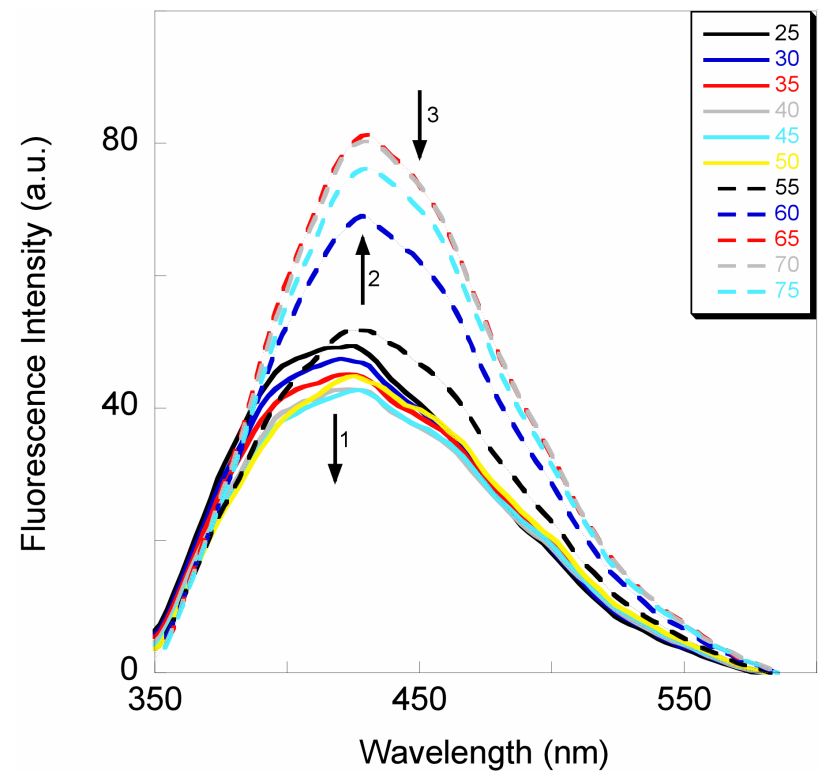


Figure S.9 Crystal Structures of 2a-2c.

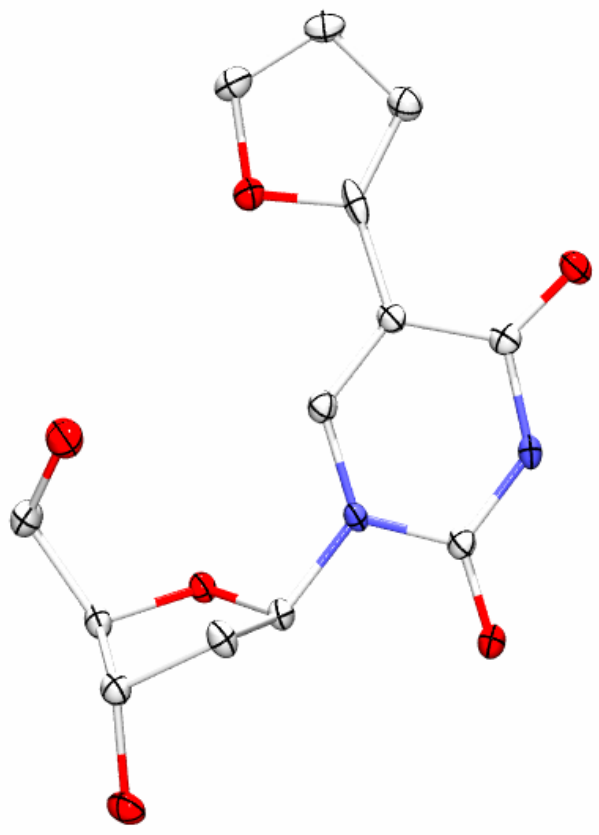

$2 a$

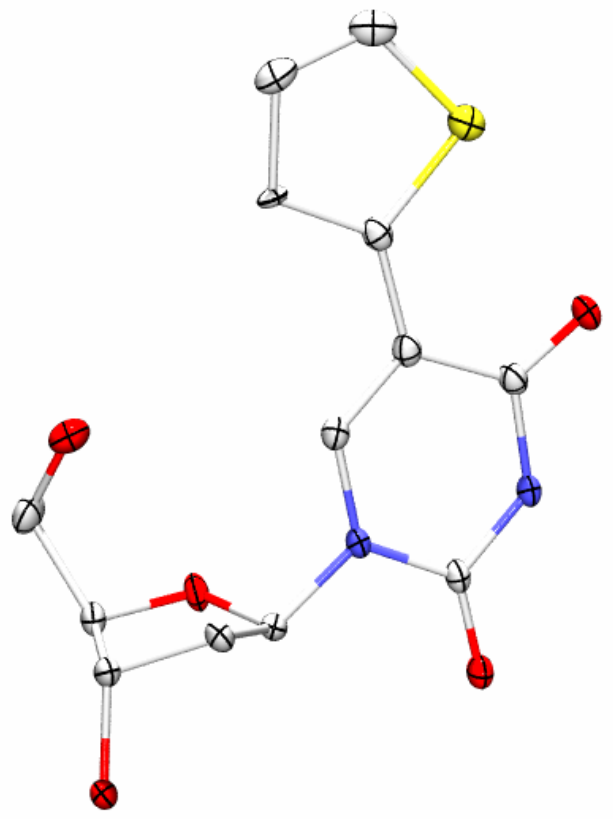




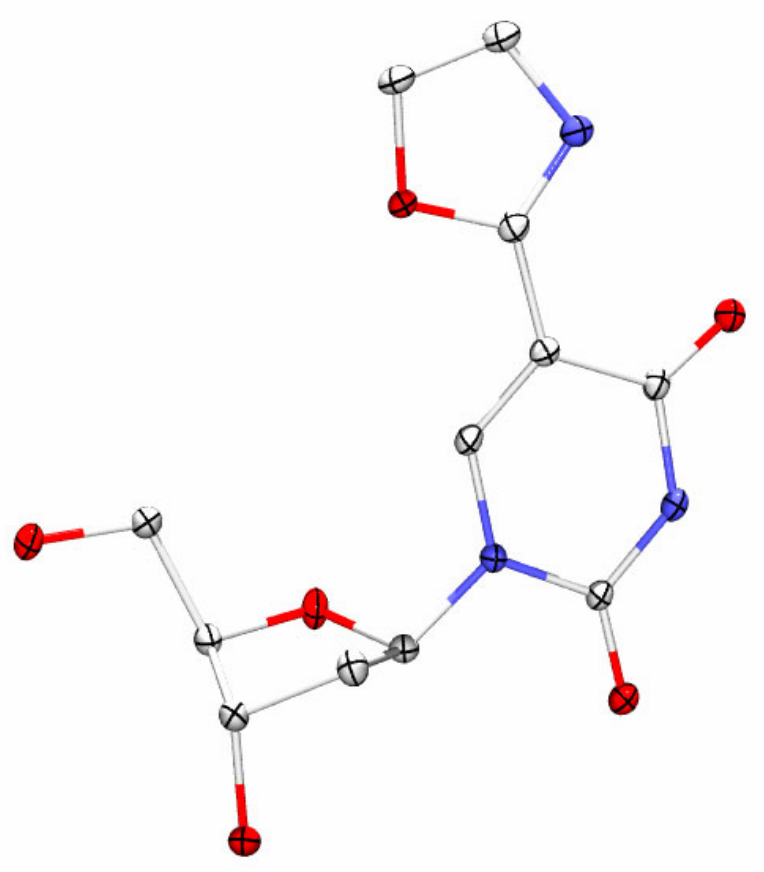

2c 